\title{
Similarities in Addressing the Complex Nature of Love and Devotion in Methamorphosis by Kafka and in ghazals of Mir Alisher Navoiy
}

\author{
Kadirova Nargiza Arivovna
}

\begin{abstract}
The great European novelist and short-story writer, Franz Kafka, and one of the most famous eastern poets of Middle ages, Alisher Navoiy, at first blush seem to have absolutely nothing in common. But a detailed analysis of two distinguished works of the writers, reveals their surprisingly similar views in regard to interpretation of love and devotion concepts. Step-by-step comparison of one of the Mir Alisher Navoiy's ghazals with The Metamorphosis of Kafka allows to correlate the messages of each masterpiece, and thus define the similarities in personal traits of each author.
\end{abstract}

Keywords : Love, devotion, The Metamorphosis, Ghazal, Kafka, Alisher Navoiy, comparative analysis, world literature.

Love: a strong affection for another arising out of kinship or personal ties [1]

\section{INTRODUCTION}

B $_{\text {oth Franz Kafka and Alisher Navoiy were }}$ among the most recognized writers of their time. Interest in their works has grown over time, and today it is safe to say that each of them left an invaluable mark in the history of the World Literature. At first glance it may seem that there is absolutely nothing in common between these two authors.

Mir Alisher Navoiy was a Chagatai Turkic [2] poet, writer, politician, linguist, mystic, and painter [3]. The greatest representative of Chagatai literature [4] Alisher Navoiy was born in Herat (currently the territory of Afghanistan) on February 9, 1441. During Alisher's lifetime, Herat was ruled by the Timurid Empire and became one of the leading cultural and intellectual centres in the Muslim world. Alisher belonged to the Chagatai amir class of the Timurid elite. He was a schoolmate of Husayn Bayqarah, who would later become the sultan of Khorasan region. Alisher's father, Ghiyath ud-Din Kichkina (The Little), served as a high-ranking officer in the palace of Shahrukh Mirza, a ruler of Khorasan. His mother served as a prince's governess in the palace [5].

As an adult Alisher performed public administrator and adviser duties in the castle of Husayn Bayqarah, sultan of Khorasan. In addition to his achievements in literature the

Revised Manuscript Received on July 22, 2019.

Kadirova Nargiza Arivovna, Interfaculty Foreign Languages Department, Bukhara State University, Bukhara, Republic of Uzbekistan Nzkd117@gmail.com writer became famous for his efforts in construction area by founding, restoring, and making endowments for 370 mosques, madrasas, libraries, hospitals, caravanserais, and other educational, pious, and charitable institutions in Khorasan. He was also reported to take part in construction of 40 caravanserais, 17 mosques, 10 mansions, nine bathhouses, nine bridges, and 20 pools in Herat [6].

While Franz Kafka a German-speaking novelist and short-story writer, widely regarded as one of the major figures of 20th-century literature, was born on July 3, 1883 in a middle-class, German-speaking Ashkenazi Jews family in the capital of the Czech Republic, Prague (at that time the capital of the Kingdom of Bohemia, a part of the Austro-Hungarian Empire). His father, Hermann Kafka (1854-1931), was the fourth child of Jakob Kafka [7], a ritual slaughterer in a Czech village called Osek in southern Bohemia, which was densely populated by Jews [8]. Hermann decided to move the family to Prague. For some time, he worked as a travelling sales representative, and then became a fashion retailer with about 15 employees. The logo of his products was a jackdaw (pronounced and colloquially written in Czech as kafka). Kafka's mother, Julie (1856-1934), was the daughter of Jakob Lowy, a prosperous retail merchant in Podebrady, and was better educated than her husband [9]. Franz trained as a lawyer and after completing his legal education was employed full-time by an insurance company, forcing him to relegate writing to his spare time [10].

The gap in five centuries, significant geographical and cultural differences, as well as discrepancy in traditions and social statuses of the Kafka and Navoiy families definitely did not contribute to the intersections in the oeuvre of each of the talents. Of course, at first glance the authors works logically look like they have nothing in common with each other.

The works of Kafka, imbued with absurdity, fear of the outside world and the highest authority, awaken relevant anxious feelings in the reader, combine elements of realism and fantasy [11] and, as a rule, tell about a person who encounters bizarre or surrealistic difficulties and incomprehensible social bureaucratic forces. Kafka's primary and prevailing motifs usually include topics of alienation, existential anxiety, guilt, and absurdity [12].

While the vast and complex creative heritage of Alisher Navoiy, which includes about 30 major works, by using the centuries-old cultural traditions of the Muslim peoples of Central Asia and the Middle East, focuses on love - a high, spiritual and refined, earthly feeling that overmasters and deprives a man of his freedom. At the same time, in Navoiy's oeuvre 
love is never associated with pessimism, since the poet sees the love suffering as the basis of spiritual rebirth [13].

\section{MATERIALS AND METHODS}

Could there be anything uniting these two completely different, in all respects, geniuses? Their work, their way of life, their environment, even the epochs in which they lived and created belong to two different worlds. However, there is one extremely important circumstance which as a common thread runs through the life course of both writers and finds its reflection in the work of each of them - it is devotion and love.

It might seem that the works of Franz Kafka are far from the poetic chanting of love, so typical of Alisher Navoiy's poetry. However, despite the significant differences between personalities of these people, which naturally affected their work, they both possess a very important unifying feature that shaped a similar philosophy in relation to the concepts of love and devotion. Both of them never married, and under the influence of external factors and personal traits, both associated love with an overly strong feeling, exceeding even the sense of self-preservation. Due their stylistics, the works of Alisher Navoiy usually lack ambiguity in interpretation, and Their metaphors are quite clear, while the works of Kafka, by virtue of their genre, have many variants of interpretations and explanations of the implied sense. For instance, let's look at Kafka's Metamorphosis:

Charles Neider (1948) sees the basic concept of the story in Kafka's father complex [14]. While Vladimir Nabokov rejected such interpretation, he instead chose an interpretation guided by the artistic detail but categorically excluded any and all attempts at deciphering a symbolical or allegorical level of meaning [15].

Nina Pelikan Straus (1989) from her own point of view described a feminist interpretation of Metamorphosis, bringing to the forefront the transformation of the main character Gregor's sister, Grete, and foregrounding the family and, particularly, younger sister's transformation in the story [16]. While Ralf Sudau (2007) took the view that particular attention should be paid to the motifs of self-abnegation and disregard for reality [17].

And there are many other noteworthy opinions about the core idea of Kafka's story, however most of them usually omit its hidden message about the power of love and self-devotion.

In order to demonstrate the existing analogy in understanding of these concepts in the works of both authors, and their importance for each of them, a comparison could be made between one of Kafka's most symbolic masterpiece, The Metamorphosis, and Alisher Navoiy's beautiful ghazal included in his Hazoyin ul- Maoniy collection [18].

\section{RESULTS AND DISCUSSION}

Dividing the work of the Uzbek poet on couplets, and comparing each of them, with the elements of Kafka's novel, unveils their close correlation from the point of figurative interpretation.

Free translation of Navoiy's first couplet says:
Do not feel thirst for the good of the world, for it grants only harm, and nothing more.

Enjoy your life because we are here just for a while, and nothing more.

In general, these two lines reflect one of the main conclusions that can be drawn from the description of Gregor Samsa's life. The protagonist of The Metamorphosis throughout the whole story craved for understanding and support of his loved ones, and, without it he died in suffering.

French literary scholar Claude David believes that the hero of the story is Kafka himself: "being transformed by his unsociable character, his penchant for loneliness, his persistent thought of being some kind of monster, he is consistently cut off from work, family, meetings with other people, he is locked in a room where no one dares to step foot and which is gradually freed from furniture, he is an incomprehensible, despised, disgusting subject in the eyes of all" [19]. However, if you look at the situation not with the eyes of surrounding people, but with the eyes of the main hero, you can see that at the root of the work lies Gregor's veiled reluctance to accept the fact of lack of love, and the resulting lack of help from people to whom he had the warmest feelings.

The second couplet of Navoiy's ghazal:

It is strange that the builder of the house invites mortals to be his guests,

After all, he himself is a short time visitor of this house, and nothing more.

correlates with the memories of Gregor, where he is proud of the fact that he could pay for his family's life in a good home on Charlottenstrasse. But after his transformation, life shows him that in this house, which he himself selected, he is only a guest for a very short period. Of course, in the work of Navoiy, the "house" has a more abstract character, but Nabokov, who carefully worked through the details of The Metamorphosis, always spoke of a certain "absurdity" in Kafka's novels, and especially in The Metamorphosis. The absurdity is that a soul placed in a body is infinitely more perfect than the latter. A person who wants to portray this absurdity should make it live in the game of specific parallels [20]. Consequently, the images in the work should be correlated with broader concepts than with specific objects defined by the meanings of terms.

The next couplet:

Do not consider yourself almighty, you are mortal; after all, the elephant is huge

But next to the mosquito sting his size is just a trace of courage, and nothing more.

can be interpreted as reflection of the inner world of Gregor, who, in full confidence of his irreplaceable importance for the family, for its well-being, suddenly realized how unstable his status was compared to the strength of circumstances. The "...photograph of Gregor when he was a lieutenant in the army, his sword in his hand and a carefree smile on his face as he called forth respect for his uniform and bearing" [21] strongly contrasts with the thoughts of a stunned, humiliated insect, with a rotten apple in its body; it symbolizes the relativity of everything in this world.

Enter the outward dwelling - you will see sheikh who is a master of trade! And even if this place is called the dervish lodge - it is 
still a misfortune trading place, and nothing more.

These lines can be associated both with the dominant position of the father within the family, a father who in the eyes of his son was at an unattainable attitude but currently in a difficult life situation, and with Gregor himself, who, as it turned out, exaggerated his role in ensuring the well-being of the family.

In the first case, Gregor's father who was announced to be bankrupt and stuck in debt, in the middle of the narrative confesses that he had saved some part of his wealth, and even succeeded to increase it while his son was working hard to earn some money for the family, and for the return of father's debts. As Nabokov writes: "It transpires that in his human past Gregor has been deceived by his family. Gregor had taken that dreadful job with that nightmare firm because he wished to help his father who five years ago had gone bankrupt" [22].

While in the second case, Gregor himself, working as a traveling salesman for a long time, and having a fairly high self-esteem in terms of the wages earned, turned out to be unnecessary and forgotten overnight.

With the further lines of ghazal:

The one in gold-embroidered clothes may unreasonably puff-up in pride:

But the sane person clearly knows that the one in golden dress is a pitiful buffoon, and nothing more.

a parallel can be drawn with the images of the three new guests of the Gregor Samsa's house; they were originally described in a laudatory manner, but after the death of Gregor, the gloss slept. Vladimir Nabokov described this episode as: "We get a wonderful glimpse of the lodgers as they sullenly ask for their breakfast but instead are shown Gregor's corpse. "So they entered and stood around it, with their hands in the pockets of their shabby coats, in the middle of the room already bright with sunlight." What is the key word here? Shabby in the sun. As in a fairy tale, in the happy end of a fairy tale, the evil charm is dissipated with the magician's death. The lodgers are seen to be seedy, they are no longer..." [23]. Underlining that the relatives of Gregor saw the light after the death of his son, and that the three gentlemen were not that important as they seemed to be.

In the next couplet, Navoiy writes:

Do not be careless, even on the throne of heaven

There won't be caress in the sky, you'll just see the dawn, and nothing more.

Drawing the analogies with Franz Kafka's novel, reveals the similarities between the state of Gregor Samsa before the transformation - a successful traveling salesman who can bear the burden of responsibility for the welfare of the family; and afterwards - the miserable, downtrodden, and hated dependent who is tolerated only under the condition that he would not leave his room. However, the main character continued his attempts to get in touch with his family to get more honors and love, which he thought he deserved and which his relatives were not ready to give him.

Similarly, in interpreting the story Ralf Sudau (2007) wrote: “Gregor's earlier behavior was characterized by self-renunciation and his pride in being able to provide a secure and leisured existence for his family. When he finds himself in a situation where he himself is in need of attention and assistance and in danger of becoming a parasite, he doesn't want to admit this new role to himself and be disappointed by the treatment he receives from his family, which is becoming more and more careless and even hostile over time" [24].

Continuation of Navoiy's ghazal:

The fair-minded lord must think of his people

After all, the shepherd made a vow to lead his herd, and nothing more.

has much in common with the brightly described feelings of Gregor Samsa in the first part of The Metamorphosis, when the responsibility and love for the family drives him out of bed during the arrival of the chief clerk, and the "herd", i.e. his family is actively pushing him to do so. This moment was very vividly described by Nabokov: "Gregor's family are his parasites, exploiting him, eating him out from the inside. This is his beetle itch in human terms. The pathetic urge to find some protection from betrayal, cruelty, and filth is the factor that went to form his carapace, his beetle shell, which at first seems hard and secure but eventually is seen to be as vulnerable as his sick human flesh and spirit had been" [25]. Samsa is a responsible lord, and his "herd" demands him to fulfill his duties.

And the last couplet of the ghazel in question is:

If Navoiy is a wanderer of his own volition now,

Do not grieve, prudent, just watch the leaving madman, and nothing more!

Just as in the final act of Mir Alisher Navoiy's poem, the main character of Kafka's novel silently leaves the stage, while the life of his family undergoes metamorphosis and, in some aspects, improves. In both cases, the authors send signals that in this cruel world sadness makes no sense in certain life circumstances, and finalize their works with an atypical, pessimistic message to make the readers think.

Thus, one can trace the semantic correlation between the works of two writers having nothing in common. The works that differ from each other in genre, style, content, period of writing, and even language are united by the common determination and focusing on the problems of loyalty, devotion, love and the frailty of life. In his final couplet, Alisher Navoiy is stating his name, thus pointing out that in the root of his ghazal lie the inner emotions based on his own life experience. As to Kafka, although he does not directly indicate a connection between himself and the main character of The Metamorphosis, the interconnection of Franz with Gregor are clearly read between the lines. And having studied the writer's biography, one can easily trace the parallels between the life of Kafka and his hero. As the reputable The Guardian stated: "There's something a little chilling in the way he could step aside from himself, perceive his own plight, then twist it with finesse into fictional shapes that had the force of parables" [26].

\section{CONCLUSION}

In other words, despite the significant differences between the authors and their works, a comparative analysis of two classical masterpieces of world literature allows to trace the close relationship between the elements relating to the concepts of love, relationships, devotion and frailty of life. Which, 
in turn, taking into account that the works are based on the authors' own experience, suggests the similarity of the internal interpretation of the view of life that the authors had under the influence of external factors and personal traits. Unlike the poetry of Alisher Navoiy, the complex figurative novel of Franz Kafka is rarely considered as a work devoted to love and family values. But Kafka's oeuvre is so versatile, that a deeper look into the writer's motives unveils existence of many new messages hidden between the lines. The outcomes of the analysis above support the idea that two authors in some points had a similar philosophy of life, and the products of this philosophy found its reflection in their literary legacy.

\section{REFERENCES}

1. Merriam-Webster Dictionary at https://www.merriam-webster.com /dictionary/love. Consulted online on June, 262019

2. Richards, John F., The Mughal Empire. Cambridge University Press, Cambridge, UK, 1995. - p. 6,

3. Subtelny, Maria E., "Ali Shir Navai", in: Encyclopaedia of Islam, THREE, Edited by: Kate Fleet, Gudrun Krämer, Denis Matringe, John Nawas, Everett Rowson. Consulted online on June, 262019

4. McHenry, Robert, ed., "Navoiy, (Mir) Alisher". Encyclopedia Britannica 8 (15th ed.) Encyclopedia Britannica, Inc. Chicago, USA, 1993. - pp. 90-93

5. Wikipedia The Free encyclopedia at https://en.wikipedia.org/wiki/Ali-Shir_Nava\%27i. Consulted online on June, 262019

6. Lovell-Hoare Sophie, Lovell-Hoare Max, Uzbekistan. Bradt Travel Guides. Chalfont St Peter, UK, 2013. - p.26

7. Gilman, Sander, Franz Kafka, the Jewish Patient. Psychology Press, East Sussex, UK, 1995. - p.88

8. Nervi, Mauro, Kafka's Life (1883-1924). 2011. at http://www.kafka.org/index.php?biography. Consulted online on June, 262019

9. John P. Anderson, Kafka's the Metamorphosis: Unwelcome at Home. Universal-Publishers, CA, USA, 2016. - p.66

10. Spindler, William, Magic Realism: A Typology, Forum for Modern Language Studies. Vol. XXIX, iss. 1. Oxford University Press, Oxford, UK, 1993 - pp. 75-80

11. Luebering, Juan Gelman, Franz Kafka, Biography \& Works. Encyclopedia Britannica at https://www.britannica.com/biography/Franz-Kafka. Consulted online on June 26, 2019

12. Kayumov Aziz, Alisher Navoiy, History of the World Literature in 9 volumes. v.3. Nauka, Moscow, USSR, 1985 - pp. 576-582

13. Neider, Charles, The Frozen Sea: A Study of Franz Kafka. Russell \& Russell, NY, USA, 1962 - p.29

14. Nabokov, Vladimir, Die Kunst des Lesens: Meisterwerke der europäischen Literatur. Fischer S. Verlag GmbH, Berlin, Germany, 1984. - pp. 313-352.

15. Pelikan Straus, Nina, Transforming Franz Kafka's Metamorphosis, Signs Journal of Women in Culture and Society, 14(3). The University of Chicago Press, Chicago, USA, 1989. - pp. 651-667.

16. Sudau, Ralf, Franz Kafka: Kurze Prosa, Erzählungen. Klett, Stuttgart, Germany, 2007. - pp. 158-162.

17. Arutyunov, L., Taneev, V., Poetry of the USSR nations of 5-18th Centuries. Library of World literature. v.55 Khudozhestvennaya Literatura, Moscow, USSR, 1972. - p.330-331

18. David, Claude, Franz Kafka. Molodaya Gvardiya, Moscow, Russia, 2008. - p.60

19. Camus, Albert, The Myth of Sisyphus, Appendix, Hope and the Absurd in the Work of Franz Kafka, Penguin, London, UK, 2013. - pp.195-205

20. Franz Kafka, The Metamorphosis. GlobalGrey. London, UK, 2018. - p.12

21. Lecture on "The Metamorphosis" by Vladimir Nabokov at http://www.kafka.org/index.php?id=191,209,0,0,1,0. Consulted online on June, 262019

22. Richard T Kelly. Kafka's Metamorphosis: 100 thoughts for 100 years. The Guardian. International edition. July 18, 2015. Consulted online on June, 262019. 